\title{
Němčina historických pramenů na Filozofické fakultě Univerzity Karlovy
}

\author{
Helena Hasilová
}

Svůj př́íspěvek bych ráda uvedla povzdechem, že současní maturanti (a to i v případě, že úspěšně absolvovali maturitu z německého jazyka) mají stejně jako celá současná populace $\mathrm{v}$ České republice velmi nízkou úroveň znalosti německého jazyka, z čehož profitují mimo jiné všechny dobré agentury zprostředkující pomaturitní výuku firemních a individuálních kurzů německého jazyka. Není zcela jasné, proč tomu tak je, protože většina minulých generací, včetně obyvatelstva, které univerzitním a mnohdy ani středoškolským vzděláním neprošlo, tímto jazykem poměrně dobře vládla. Důvodem může být všeobecně propagovaná idea o nezastupitelné roli angličtiny, nedobrá úroveň byt' velkého množství učebnic, nebo nevhodná politika ředitelů škol při výběru učitelů.

Náš příspěvek se ovšem chce zaměřit na to, jakým způsobem má učitel němčiny filozofické fakulty pracovat se studenty, kteří obvykle nevládnou němčinou ani na úrovni B1 a kteří jsou přijati do prvního ročníku studijního programu archivnictví a pomocné vědy historické. Jak s nimi pracovat, aby na konci bakalářského studia byli schopni jednak složit zkoušku B2 podle SERR, jednak, a to je z hlediska jejich oboru daleko důležitější, aby mohli v archivu číst a překládat středověké prameny a mohli být nápomocni $\mathrm{v}$ tomto ohledu uživatelům archivu - historikům, lidem sestavujícím svůj vlastní rodokmen, hledajícím spravedlnost z hlediska jejich bývalého majetku a majetku celých rodin.

Připravit studenty ke složení zkoušky B2 podle SERR je schopno každé dobře fungující jazykové centrum nebo jazyková škola, at' se jedná o jazyk anglický, německý nebo další. Ale metodika výuky středověké a raně novověké němčiny zatím vypracována není a z hlediska mnohých didaktiků se v tomto případě vzdělávání jedná pouze o jazykovou výchovu směřující k úrovni B2-C1 s profesním zaměřením. Málokdo z učitelů ostatních cizích jazyků (ale i učitelů německého jazyka) si ale umí vůbec představit text psaný gotickým písmem či kurentem, text středověký nebo novověký, se kterým je absolvent oboru archivnictví ve své odborné praxi konfrontován.

Naše země je specifická tím, že se v rodinách i ve veřejném a hospodářském životě setkávali Češi a Němci. A v archivech se dnes tudíž prolínají české a německé prameny. Z toho vyplývá nepominutelně důležitá role vzdělávat archiváře tak, aby byli schopni tyto prameny rozklíčovat a zpřístupnit badatelům. Navíc je třeba docílit u studentů schopnosti velkého stupně jistoty a přesnosti čtení s porozuměním těchto textů, nebot' mnohdy i nepatrná nedokonalost může ovlivnit další, mnohdy 
i soudní, jednání související například s dědictvím nebo restitucemi. Ovšem ani produktivní dovednosti (obzvláště psaní) nemohou zůstat stranou, protože se na archivy obracejí potomci v Čechách dříve žijících obyvatel a ti si žádají výklad archiválie $\mathrm{v}$ cizích jazycích a podle informací pracovníků badatelen $\mathrm{v}$ pražských archivech poptávka po regestech $v$ němčině výrazně převyšuje poptávku po regestech v jiných jazycích.

Tuto zdánlivě neřešitelnou situaci se rozhodl řešit tým spolupracovníků katedry archivnictví a pomocných věd historických FF UK pod vedením doc. Ebelové, který otevřel kurz celoživotního vzdělávání (CŽV) s názvem Němčina pro archivní $a$ badatelskou praxi, jenž je určen studentům archivnictví, ale i široké odborné veřejnosti, včetně zájemců z řad studentů Univerzity třetího věku (U3V).

Na rozdíl od běžných kurzů němčiny $\mathrm{v}$ rámci studia je zde možno se skutečně intenzívně zaměřit na dovednosti a s nimi spjaté gramatické struktury a lexikální komponenty, které absolventi budou opravdu potřebovat a nezabývat se elementy podle velmi všeobecně a široce pojatého Společného evropského referenčního rámce pro jazyky, z nichž některé jsou opravdu pro danou cílovou skupinu uživatelů jazyka (pracovníků v archivech) marginální. Připomeňme v této souvislosti témata aktuálně předepsaná pro kurzy němčiny Jazykového centra FF UK, jako např. psaní životopisu, vyprávění děje filmu, komentář grafů a statistik, pojednání o cestování a vztazích mezi lidmi nebo popis místnosti či hovoření o nereálných dějích. $O$ převádění nominálních vazeb na verbální nebo infinitivních vazeb na vedlejší věty apod. ani nemluvě.

Jako vyučující a iniciátorka vzniku tohoto kurzu bych se chtěla podělit o své zkušenosti, jak postupuji $\mathrm{v}$ těchto profesně zaměřených kurzech, aby i v současných neutěšených podmínkách bylo možno přijatelné jmenované úrovně znalostí a dovedností u studentů dosáhnout.

Po celou dobu kurzu je třeba mít na zřeteli následující:

Úvodem je vhodné přehledně provést zopakování, doplnění a částečně i „dovysvětlení" základních gramatických a jazykových konstrukcí tak, aby frekventanti za pomocí slovníku byli schopni porozumět výpovědím proneseným či přečteným $\mathrm{v}$ indikativu prézentu, préterita a perfekta, a to $\mathrm{v}$ aktivu i pasivu. Tyto gramatické konstrukce je třeba představovat a cvičit na slovní zásobě a větách z oblasti tématikou moderních dějin počínaje a přecházeje co do volby textů plynule k obdobím starším. Dále je třeba od samého počátku zařadit seznámení s prací se slovníky, a to nejen současného jazyka. Studenti musejí mít přehled o tom, které slovníky jsou v kterých knihovnách, př́ípadně a zejména při on-line výuce, které slovníky jsou $\mathrm{k}$ dispozici $\mathrm{v}$ elektronické formě. Studenti se tímto postupem seznamují prakticky se slovní zásobou jednotlivých historických období, přičemž ovšem nesmí chybět doplnění výkladu vývoje historické mluvnice ze strany učitele nebo alespoň dopo- 
ručení přehledu vývojových tendencí, které jsou v sekundární literatuře, ale i na mnohých místech dostupné on-line. Toto je možné zařadit souběžně s nácvikem produktivních dovedností již na úrovni B1. Například při nácviku psaní pojednání o oblíbené historické epoše nebo shrnutí obsahu historického textu přečteného v němčině nebo i v jiném jazyce. Při analýze, vysvětlování a diskusi o formálních nedostatcích vyprodukovaného textu mezi učitelem a samotnými studenty mezi sebou je možno opakovat a upevňovat již vysvětlené gramatické a lexikální struktury. Na takovýto písemný referát může student navázat referátem ústním, v němž bud' shrne hlavní myšlenky, nebo se zaměří na jeden z aspektů. Studenti si témata volí sami, logicky si tedy zvolí téma sobě blízké. Tím je zaručena jejich vysoká motivace a zaujetí. V rámci prezentace provádějí studenti ve skupině seznámení $\mathrm{s}$ užitou slovní zásobou, a to v ústní i psané podobě (k tomuto přispívají studenty oblíbené powerpointové prezentace).

Cílem je dosažení následujících jazykových dovedností:

\section{Dovednosti receptivní}

U nácviku čtení s porozuměním je třeba rozlišovat různé druhy čtení podle účelu. Jednak musí absolvent oboru archivnictví na základě globálního čtení umět zhruba rozklíčovat obsah německé archiválie, což postačuje pro účel evidence archiválií s uvedením obsahu, ale student musí být vybaven i schopností poměrně podrobného a přesného překladu textu jdoucího ruku v ruce také s paleografickým přepisem. Je ještě třeba připomenout, že $v$ tomto kurzu je věnována pozornost i současným odborným historickým textům, protože se zde někteří studenti připravují na zkoušku B2. Ovšem nad rámec této zkoušky je třeba seznámit studenty s možnostmi, jak je možné porozumět tvarům nářečním, či jak určit hodnotu měr a vah, které se v různých obdobích v Čechách a na Moravě užívaly.

Poslech s porozuměním se stává aktuálním u několika málo absolventů, kteří se vydají na vědeckou dráhu, a počítá se s tím, že budou účastni zasedání v němčině, i když většina konferencí předepisuje jako konferenční jazyk angličtinu ${ }^{1}$. Ale pro práci $\mathrm{v}$ archivu je třeba připravit absolventy $\mathrm{v}$ první řadě na situaci, kdy musejí reagovat na telefonické nebo prrímé dotazy badatelů, což samozřejmě predikuje porozumění kladenému dotazu.

\section{Dovednosti produktivní}

Co se ústních komunikátů týče, je stěžejní nácvik ústního referátu s následnou diskusí a dále seznámení budoucích pracovníků v badatelnách se způsobem ústní komunikace s německými badateli. Při tom je třeba se zaměřit na komunikaci

\footnotetext{
1 Naprosto nelogicky i v případě, že účastníci pocházejí z německy mluvících zemí, což je v poslední době kvůli nejasnostem v terminologii samotnými německými jazykovědci kritizováno.
} 
při vyhledávání archiválií, při určování ceny kopií, na chování v badatelně a na informace o možnostech zasílání kopií ve formě papírové nebo elektronické.

Pro tento kurz má význam zařazení nácviku prezentace odborného referátu s následnou diskusí, protože se jedná o významnou produktivní dovednost a také proto, že se jedná o aktivitu vedoucí $\mathrm{k}$ volnému vyjadřování myšlenek v komunikaci, o rozšiřování slovní zásoby ani nemluvě. A to i za předpokladu, že jsme si vědomi toho, že ne všichni absolventi oboru archivnictví a pomocných věd historických mají vědecké ambice, a budou své myšlenky $\mathrm{v}$ němčině prezentovat. Zařazení těchto aktivit do výuky vede i $\mathrm{k}$ přirozené komunikaci o jednotlivých historických tématech, při nichž dochází $\mathrm{k}$ vyjadřování názorů celé skupiny.

K nácviku ústního referátu, jak již bylo zmíněno, lze přistoupit ihned po úvodním shrnutí německé gramatiky na úvod kurzu, a to již na úrovni B1 podle SERR. Student po vzoru přečtených textů produkuje jednoduché výroky o historické epoše, události či osobnosti, nebo shrne hlavní myšlenky přečteného textu, kdy nemusí být podmínkou, aby text, který je komentován, byl nutně studentem přečten $\mathrm{v}$ němčině. Za pozitivní považujeme i přirozenou nápodobu jazykových struktur.

Kromě nácviku ústního referátu je třeba dále seznámit posluchače se zdvořilostními formami pro styk s badateli. Za tímto účelem je nejefektivnější sestavení modelových dialogů a jejich nácvik v párové a skupinové komunikaci.

Co se produkce písemných textů týče, je jednou ze součástí kurzu zformulovat písemný referát (esej), což je také jedním z požadavků pro složení zkoušky B2, ale důležitější je nacvičit psaní regestů v němčině, protože si je žádají i archivy na německy mluvícím území. Mnohdy je nutno poř́́dit překlad listiny do češtiny a ještě dále i do současné němčiny. $V$ neposlední řadě je nutno nacvičit schopnost odpovědět na písemný dotaz tazatele $v$ němčině. Př́prava na písemnou komunikaci v archivu s tazateli a badateli z Německa, Rakouska či Švýcarska se stává bezpodmínečnou součástí kurzu, protože k psaní emailů v němčině bude archivář nucen přistoupit zcela určitě ve svém pracovním, ale i soukromém životě.

Významnou dovedností, kterou v kurzu nacvičujeme, je psaní regestů, to znamená stručného shrnutí obsahu archiválie. Je to pro studenty často problematické, a to jak v němčině, tak češtině. Dotazem směřujícím ke studentům, pracovníkům archivu Státního oblastního archivu v Praze, kteří studovali obor na různých univerzitách Čech a Moravy, i k vedoucí katedry archivnictví a pomocných věd historických jsme zjistili, že psaní regestů je nacvičováno pouze okrajově při hodinách diplomatiky a slouží hlavně ke zjištění pochopení textu u studentů, než že by byla vypracována a užita metodika jeho produkce. Absolventi oboru archivnictví se vyjadřují v tom smyslu, že „snad u jedné listiny zkoušeli regest vytvořit a potom s nimi přišli do styku hlavně při psaní seminárních prací jako uživatelé“. Psaní nových regestů je tedy většinou pouhou nápodobou regestů produkovaných před- 
chůdci. V archivech regesty vytváří pracovník, jehož funkce je označována jako zpracovatel archivní pomůcky (např́íklad inventáře). Př́padně, pokud jsou listiny zveřejňovány např́klad na virtuálním archivu Monasterium, vytvář́ je osoba, která je „projektem na tuto činnost najata“. A také pro tyto pracovní pozice studenty vychováváme.

Pro zájemce budiž uvedeno, že norma pro psaní regestu je k nalezení v materiálu Základní pravidla pro zpracování archiváliií ${ }^{2}$, která ale pro naše účely není použitelná.

Pokud necháme studenty produkovat regest bez cílené př́pravy, ukazuje se, že studenti nejsou správně vedeni ke kondenzaci textů, což je s podivem, protože v sylabu jazykových center bývá uveden jako jeden z bodů psaní resumé, což je slohový útvar velmi obdobný.

Úvodem je velmi vhodné uvést definici tohoto slohového útvaru. Za tímto účelem užívám heslo z České terminologické databáze knihovnictví a informačních věd (TDKIV). ${ }^{3}$

Protože se jedná o kurz němčiny, je velmi vhodné seznámit studenty i s německou verzí vysvětlení ${ }^{4}$.

Pro ilustraci uvádíme ukázku archiválie zcela běžného typu textů, s jakými jsou archiváři ve výuce a posléze při své vlastní práci konfrontováni.

Je to dopis královny Žofie Bavorské, vdovy po českém králi Václavu IV., který odeslala za svého pobytu v Bratislavě svému bratrovi Arnoštovi do Mnichova. Vyda-

\footnotetext{
2 Michal Wanner, Základní pravidla pro zpracování archiválií, Odbor archivní správy a spisové služby MV, Praha 2015.

3 „Regest je krátké shrnutí listiny či jiné písemnosti, a to jak za vědeckým, nebo úředním účelem. Podle rozsahu se rozlišuje regest záhlavní (inventární záznam) a náhradní (katalogizační záznam). Záhlavní je kratší, obsahuje jen krátkou zmínku o pořízení, při použití v edici pramenů často za tímto regestem následuje listina v plném znění. Náhradní navíc obsahuje všechna místní jména, plné tituly apod.“

4 „Als Regest bezeichnet man in der Geschichtswissenschaft die Zusammenfassung des rechtsrelevanten Inhalts von Urkunden des Mittelalters und der Frühen Neuzeit. Unter dem Plural Regesten versteht man auch eine besondere Publikationsform, die Urkunden eines Ausstellers, einer Provenienz oder eines Betreffs - geordnet nach Datum - nachweisen und mit inhaltlichen Zusammenfassungen, Nachweisen über die Überlieferung und quellenkritischen Hinweisen ergänzen. Vom Umfang her unterscheidet man zwischen dem Kopfregest oder Kurzregest, das Aussteller, Empfänger, Ort und Datum einer Urkunde sowie eine kurze Zusammenfassung ihres rechtlichen Inhalts enthält, und dem Vollregest mit einer ausführlicheren Beschreibung des Rechtsinhalts unter Nennung aller genannter Namen, teils einschließlich der Zeugen. Auch Hinweise zur Art der Beglaubigung sowie eine Zusammenfassung der Narratio können in einem Vollregest enthalten sein. Kurzregesten erscheinen üblicherweise in Urkundeneditionen vor dem eigentlichen Text der Urkunde, während Regesten im Sinne der Publikationsform normalerweise Vollregesten enthalten." (Hanns Leo Mikoletzky: Regesten und Regestentechnik. In: Anzeiger der Österreichischen Akademie der Wissenschaften. (= Philosophisch-historische Klasse. 87) 1950, s. 240-254.)
} 


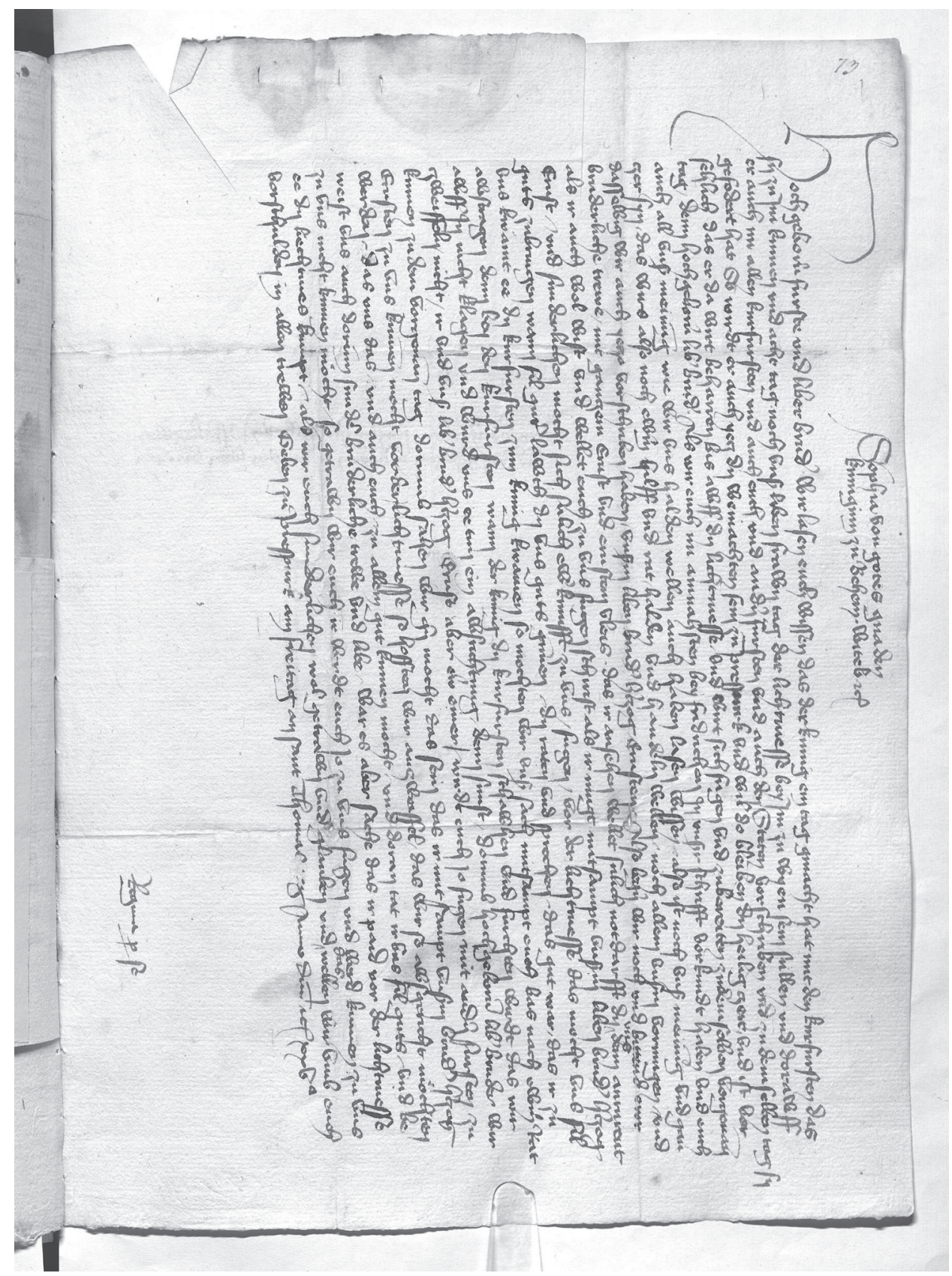

Obr. 1: Žofie 27

vatelem listu psaného 21. prosince 1424 je mělnický probošt Zikmund z pověření královny (Ad mandatum Regine Sigismundus etc.).

Pro čtenáře, kteří nejsou zběhlí ve čtení středověkých textů, a není jim na první pohled zřejmý ani přibližný obsah textu, doplňme, že se jedná o list z 21. prosince 1425 a královna zde oznamuje Vilémovi, že chce Zikmund konat osm dní po Hromnicích (10. února) ř́šsský sněm ve Vídni a tam se chce sejít s ním i dalšími 
kurfiřty, vévody i zástupci měst. Král Zikmund má být na Vánoce v Bratislavě, kde chce strávit celé svátky, a zřejmě tam setrvá až do Hromnic a bude se připravovat na sněm. $V$ souladu s tím, jak mu již psala prostřednictvím jejich př́buzného Friedricha, se chce řídit jejich radami, a proto také psala vévodovi Arnoštovi. Žádá Viléma, aby spolu s Arnoštem za ní přijeli do Bratislavy ještě před Hromnicemi a před př́jezdem kurfiřtů, což by jí přineslo mnoho užitku, nebot' by s jejich pomocí dořešila svoje záležitosti. Na závěr vyjadřuje svou domněnku, že je možné, že když přijedou, bude se král obávat, aby na něho nežalovala, a tím dř́ive bude dosaženo dohody o vyrovnání.

Podívejme se blíže na to, jak studenti musejí $\mathrm{k}$ textu přistoupit: Nejprve musí provést paleografický přepis. Na to jsou studenti na své mateřské katedře poměrně dobře připravováni, i když i zde je možné na základě rozklíčování významu mnohé přepisy přepracovat nebo upřesnit. Např́lklad při přepisu tohoto textu zaměnila studentka archivnictví na 5. rádku im za správné $n u$, neoddělila jednotlivá slova u zudemselben, což jí posléze ztížilo překlad, na 10. řádku zaměnila wns „uns nám“ za wers „wäre es - bylo by“ a hilff za hulff, což jí již význam posunulo velmi. Dále jí zcela vypadla předložka mit před vazbou handeln wellen noch allem vns[er]em vormugen. 0 tom, že se studentka neinformovala dobře ve slovníku o významu slova, svědčí uvedení tvaru schnist namísto běžně užívaného schirist „so schnell wie möglich - co nejrychleji“ (řádek 13).

Regesty $\mathrm{v}$ českém a německém jazyce, které $\mathrm{k}$ tomuto textu studentka odevzdala, vypovídají mnohé o nastíněné problematice. Jednak došlo $\mathrm{k}$ neúplnému porozumění textu, což pramení hlavně z nesprávně určeného významu slova tag, kdy pohledem do slovníku není obtížné určit, že kromě významu „Tag - den“ označuje ve středověku toto slovo také „Tagung - jednání, sněm“. Tímto zdánlivě ne tolik významným rozdílem v chápání významu jednoho slova ale vypadla z regestu významná obsahová část.

\section{Regesty - studentské práce:}

$\mathrm{V}$ češtině:

Prešpurk, 21. prosince 1425

Žofie Bavorská žádá svého bratra (Viléma), aby přijel stejně jako jejich bratr (bavorsko-mnichovský vévoda) Arnošt ke králi, který bude již na Vánoce vPrešpurku a chystá se tam setrvat, aby mohli skrálem projednat jistou záležitost ještě dříve, než ve stanovený čas - na Hromnice - přijedou kurfiřti a ostatní knížata, jak bylo králem dříve určeno.

$\mathrm{V}$ němčině: 
Sophia von Bayern bittet ihren Bruder (Wilhelm), wie ihren Bruder (Herzog von Bayern-München) Ernst, zum König zu kommen, der zu Weihnachten in Preßburg sein und dort bleiben wird, damit sie eine bestimmte Angelegenheit mit dem König besprechen können, bevor die Kurfürsten und andere Fürsten in der bestimmte Zeit - auf dem Lichtmess - kommen, wie es vom König festgelegt war.

Regest v němčině se vyznačuje správným jednoduchým vyjádřením (až na již jmenovanou chybějící část) obsahu listu. Ovšem z formy je patrná nejednotnost při označení zúčastněných osob (jednou je v závorce jméno, podruhé titul), nedostatky v koncovkách a volbě předložek.

Jak je vidět z tohoto textu, vyznačují se středověké i novověké texty volným řazením myšlenek za sebou bez řádných (z dnešního pohledu odpovídajících) spojovacích výrazů, což ztěžuje pochopení a vyvolává na některých místech i možnost vícerého výkladu významu. Studenty je třeba upozornit i na časté elipsy některých podstatných větných členů.

Psaní regestu vychází z dobrého pochopení zpracovávaného textu. Po této „přípravné“ fázi se nám osvědčilo napsání regestu v mateřštině studentů, tedy především v češtině. Je to vhodné $\mathrm{z}$ důvodu lepší možnosti kontroly německého regestu učitelem. Na druhou stranu zůstává otázkou, zda tímto nemůže docházet k interferenci z češtiny. Ale bez české verze někdy učitel jen těžko porozumí studentově záměru.

Jako další krok při přípravě na tuto produkci se nám osvědčilo zopakování veškerých gramatických jevů od koncovek adjektiv, substantiv, tvarů minulých časů, pasiva přes nominalizaci a verbalizaci s přihlédnutím ke slovosledům a upozornění na nutnost užívat současnou pravopisnou normu.

Dalším důležitým upozorněním je, aby se studenti nenechali ovlivnit historickou slovní zásobou a neužívali archaismy a dnes již neužívaná slova v současném textu, kterým regest je. Studenti si musí uvědomit, že i některá slova, která ze současného jazyka znají, mohla změnit svůj význam, a tudíž se musí překládat jinak. Takovým př́́kladem je mimo jiné středohornoněmecké slovo arbeit, které v té době znamenalo „Mühe - snaha, úsilí“ a není ho možné dnes překládat ve všech kontextech jako „Arbeit - práce“.

Z dalších frekventovaných nesrovnalostí, které je třeba eliminovat, je možno jmenovat (př́íklady pocházejí ze studentských regestů odevzdaných v minulém školním roce):

- nesprávné užívání členů nebo jejich úplné vypouštění (zde se jedná zřejmě o interferenci z češtiny) Auf Schloss namísto auf dem Schloss „na zámku“ 
- užití chybných slovesných tvarů, jako např. Karl befehlt pro Karl befiehlt - „Karel rozkazuje“"

- užití tvaru substantiva bez koncovky: Ich habe den deutschen Name von Trutnov verwendet.

Ich habe den deutschen Namen verwendet. - „Užil jsem německé jméno pro Trutnov."

- nesprávná volba předložky Am 17. Februar 1484 ist bei Vladislav in Trautenau Friedrich von Schumburg gekommen, - namísto Am 17. Februar ist zu Vladislav in Trautenau Friedrich von Schumburg gekommen. - „17. února přišel k Vladislavovi v Trutnově k Vladislavovi Fridrich ze Šumburka."

- užití slova z původního textu v regestu, přičemž dnes má slovo jiný význam In dem zweiten Brief schrieb der König Ladislav zu dem berühmten Hans von Trautenau - namísto dem schon genannten (berühmt má dnes význam „slavný")

- užití neurčitého členu u řadové číslovky namísto členu určitého hat einen dritten Brief gezeigt pro hat den dritten Briefgezeigt - „ukázal třetí dopis“.

- užití archaické předložkové vazby např. zu Trautenau namísto in Trautenau „V Trutnově“.

- psaní malého písmene u substantiv von könig Wladislaus namísto von König Wladislaus - „od krále Vladislava“.

- prohřešek proti správnému slovosledu, jako např. Wenn Balduin in einem anderen Fall

als dem Krieg mit Bayern Hilfe braucht, er zahlt die Kosten - namísto zahlt er die Kosten.

- ačkoli je možné vést diskuse o volbě užití českých či německých podob vlastních jmen anebo zachování podob jmen vyskytujících se v historických pramenech $\mathrm{v}$ regestech, existují případy, kdy je užití české podoby vyloučené. Jako např́lklad u regestu k pramenu, kde vystupuje Ulrich von Hanau. Student semináře se uchýlil k následujícím formulacím: Der römische Kaiser Ludvík verpfändet die Einwohner und die Stadt Geylehnusen den Adligen Oldřich von Hanau und seinen Erben als Belohnung ...Die Einwohner der Stadt sind Oldřich treu, bis das Versprechen aufgehoben wird.

I když to nebylo původně předvídáno, ukázalo se v době koronavirové krize, že je tento kurz velmi vhodný i pro on-line výuku.

Jednak proto, že jsou mnozí účastníci kurzu studenty distančních studijních programů a musí promyšleně dělit svůj čas mezi „pracovní“ a „studijní“ a jednak i proto, že má-li být intenzivně pracováno s historickým textem, je k tomu třeba náležitého klidu. Každý student jako individualita potřebuje různě dlouhou fázi př́ípravy a také si může vybrat denní či noční dobu pro optimální koncentraci. 
Kromě několika opravdu nutných kontaktních hodin je totiž možné pracovat distančně, na dálku, on-line.

Kurz je tedy on-line organizován tak, že je úvodem určeno několik kontaktních hodin, kdy se celá skupina „sejde“ přes ZOOM a zde učitel vyloží opěrné body z hlediska gramatiky a zadá úkoly. Výborně se hodí texty ke čtení s porozuměním s úkoly typu „Přiřad'te nadpisy k odstavcům“, „Určete, které z výpovědí odpovídají obsahově přečtenému textu“, „shrňte krátce obsah“, případně doplňovací cvičení na lexikální či gramatické jednotky. Učitel může na emailem zaslaná řešení krátce a jednoduše reagovat a student př́ípadné nedostatky opraví. Oblíbené pro distanční práci jsou přehledy frází pro komunikaci $\mathrm{v}$ archivu, německých výrazů $\mathrm{z}$ oblasti měr a vah, datací, německých názvủ českých měst, vesnic či řek, které učitel zašle studentům jen částečně kompletované a studenti za pomoci doporučené literatury, internetu, vlastních pozorování nebo i za pomoci dotazů v archivech v Česku i Německu a Rakousku doplňují výrazy a názvy. V jednom z úvodních kontaktních setkání je vhodné dále vybrat a zadat témata pro referáty. Referáty je třeba nejprve vypracovat písemně a poté, co učitel text opraví a zašle studentovi zpět, je možné, aby byl pronesen v kontaktní hodině referát ústně. K tomu je velmi vhodná powerpointová prezentace s uvedením stěžejní slovní zásoby, protože toto slouží celé skupině $\mathrm{k}$ rozšíření slovní zásoby. $\mathrm{V}$ tomto bodě je třeba upozornit na velkou nutnost dodržení času určeného pro jednotlivé prezentace, protože se studenti musí nutně vystř̌́dat a je bezpodmínečně nutné vyšetřit i chvilku na následnou diskusi.

Ta část kurzu, kdy se německé texty převádějí do současné němčiny či překládají do češtiny (mnohdy se na přání studentů provádí i paleografický přepis), se pro on-line výuku prímo nabízí. Studenti svou verzi pošlou učiteli a ten ji (pravdou je, že mnohdy i opakovaně) opoznámkuje. Některé body překladu či sporné části lze prohovořit v některé z kontaktních hodin.

Pokusila jsem se v tomto př́spěvku shrnout své dlouholeté zkušenosti i zkušenosti $\mathrm{z}$ doby zcela nedávné (koronavirové) z výuky německého jazyka pro katedru archivnictví a pomocných věd historických na FF UK v Praze. Snad budou užitečné a inspirativní i pro další němčináře. 


\section{Autorka}

PhDr. Helena Hasilová, Ph.D., e-mail: Helena.Hasilova@ff.cuni.cz

Helena Hasilová je zaměstnankyně Jazykového centra FF UK a externí vyučující katedry pomocných věd historických a archivního studia FF UK. Vystudovala obor učitelství předmětů český jazyk a literatura a německý jazyk a literatura na FF UK (1979-1984), titul PhDr. získala v r. 1984 (obor německý jazyk). Titul Ph.D. obhájila na PedF UK v r. 2008 na základě disertační práce Lingvodidaktické problémy výuky odborného vyjadřování v němčině. Absolvovala tři dlouhodobé studijní pobyty vNěmecku (Halle, Bonn, Výmar), přednášela na univerzitách v Berlíně, Lipsku a Lvově. Helena Hasilová dlouhodobě spolupracuje i s Ústavem bohemistických studií FF UK při výuce češtiny pro cizince (20 let působila jako lektorka na Letní škole slovanských studií). Je autorkou jedné monografie, spoluautorkou tří dalších, autorkou či spoluautorkou 17 učebnic vydaných v Česku, Německu a na Ukrajině a autorkou řady odborných článků publikovaných v Česku, Německu, Francii a na Ukrajině. Odborně se věnuje především vývoji německého jazyka, jazykové analýze středověkých německých textů a otázkám lingvodidaktickým. Jako pedagog zajišt'uje výuku předmětů praktického německého jazyka, práce s německými historickými prameny a němčiny pro archiváře a historiky. 